\title{
Streptococcus garvieae sp. nov. and Streptococcus plantarum sp. nov.
}

\author{
By M. D. COLLINS, ${ }^{1}{ }^{*}$ J. A. E. FARROW, ${ }^{1}$ B. A. PHILliPS ${ }^{1}$ AND \\ O. KANDLER ${ }^{2}$ \\ ${ }^{1}$ Department of Microbiology, National Institute for Research in Dairying, Shinfield, \\ Reading RG2 9AT, U.K. \\ ${ }^{2}$ Botanisches Institut der Universität, Menzinger Strasse 67, 8000 München 19, F.R.G.
}

(Received 25 May 1983; revised 18 July 1983)

Biochemical and chemotaxonomical studies were performed on some streptococci from frozen peas and bovine mastitis in an attempt to clarify their taxonomy. The results of the present and earlier studies indicate the pea and mastitis isolates represent two new species of the genus Streptococcus. The isolates from frozen peas are named Streptococcus plantarum sp. nov. and those from mastitis, Streptococcus garvieae sp. nov. The type strains are NCDO 1869 and NCDO 2155, respectively.

\section{INTRODUCTION}

At present only three species of streptococci are recognized which grow at $10^{\circ} \mathrm{C}$ but not at $45^{\circ} \mathrm{C}$ : Streptococcus lactis, S. cremoris and S. raffinolactis (Deibel \& Seeley, 1974; Garvie, 1978; Skerman et al., 1980). All three species contain the serological group $\mathrm{N}$ antigen. There have been reports of other streptococci which behave similarly under these temperature conditions but which cannot be allocated to any of these three species (Cavett et al., 1965; Garvie et al., 1981). Cavett et al. (1965) reported the isolation of some arginine-negative, group $\mathrm{N}$ streptococci from frozen peas, which apparently resembled $S$. cremoris. Subsequent studies have confirmed that these strains possess the group $N$ antigen (Cavett \& Garvie, 1967), although they were unrelated to other group N streptococci on the basis of DNA-DNA homologies (Garvie et al., 1981). Similarly, Garvie et al. (1981) described the characteristics of some streptococci from bovine mastitis which biochemically and physiologically resembled $S$. lactis. Despite the phenotypic resemblance of these mastitic streptococci and $S$. lactis, these taxa were shown to be genetically quite distinct (Garvie et al., 1981).

In the present paper additional biochemical and chemotaxonomical studies have been performed on the mastitic and pea streptococci in an attempt to further clarify their taxonomy.

\section{METHODS}

Cultures and cultivation. The test strains are listed in Tables 1 and 2. Cells for cell wall and lipid analyses were grown in yeast glucose phosphate broth (Garvie, 1978) at $30^{\circ} \mathrm{C}$ for $3 \mathrm{~d}$. Cultures were checked for purity, harvested by centrifugation, washed with distilled water and freeze-dried.

Cell wall peptidoglycan. The peptidoglycan type of two strains (NCDO 1869 and NCDO 2155) was determined. Purified walls were prepared from about $500 \mathrm{mg}$ of dry cells as described by Schleifer \& Kandler (1972). The amino acid composition of the wall hydrolysates was determined by paper chromatography and an automatic amino acid analyser (Schleifer \& Kandler, 1972).

Fatty acid analyses. Dry cells (approximately $50 \mathrm{mg}$ ) were degraded by acid methanolysis and fatty acid methyl esters examined by GLC as described previously (Farrow et al., 1983).

Isoprenoid quinone analyses. Isoprenoid quinones were extracted from dry cells (approximately $200 \mathrm{mg}$ ) and purified as described previously (Collins et al., 1977). Mass spectra of the quinones were recorded on an AEI MS9 instrument using a direct insertion probe, an ionizing voltage of $70 \mathrm{eV}$ and a temperature of $200^{\circ} \mathrm{C}$. Quantitative determination of the quinones was by HPLC as described by Collins et al. (1982). 


\section{Table 1. Percentage fatty acid composition of test strains}

\begin{tabular}{|c|c|c|c|c|c|c|c|c|c|c|c|}
\hline Assignment & $C_{12: 0}$ & $\mathrm{C}_{14: 0}$ & $C_{15: 0}$ & $C_{16: 0}$ & $C_{16: 1}$ & $\begin{array}{c}\text { iso- } \\
\mathrm{C}_{16: 0}\end{array}$ & $C_{17: 0}$ & $\mathrm{C}_{18: 0}$ & $\begin{array}{c}C_{18: 1} \\
\omega 7\end{array}$ & $\begin{array}{c}C_{18: 1} \\
\omega 9\end{array}$ & $\Delta \mathrm{C}_{19}$ \\
\hline \multicolumn{12}{|c|}{ Streptococcus cremoris } \\
\hline NCDO 508 & - & $3 \cdot 0$ & - & 29.0 & 1.5 & - & - & $6 \cdot 5$ & 31.5 & 1.5 & 27.0 \\
\hline NCDO 607 & - & 3.5 & - & 33.0 & $2 \cdot 5$ & - & - & $5 \cdot 0$ & 27.0 & 1.5 & 27.5 \\
\hline NCDO 1986 & - & $3 \cdot 5$ & 0.5 & 33.0 & $2 \cdot 5$ & - & - & $7 \cdot 5$ & 26.5 & $2 \cdot 0$ & 24.5 \\
\hline \multicolumn{12}{|l|}{ S. garvieae } \\
\hline NCDO 2155 & - & 4.5 & - & 38.0 & 1.5 & - & 3.5 & 14.5 & 25.5 & 1.5 & 11.0 \\
\hline NCDO 2156 & - & $3 \cdot 5$ & 0.5 & 36.0 & 1.5 & - & $2 \cdot 5$ & 15.0 & 27.5 & $2 \cdot 5$ & 11.0 \\
\hline NCDO 2157 & - & 3.5 & 0.5 & 36.5 & 1.0 & - & $2 \cdot 0$ & $13 \cdot 5$ & 26.5 & $2 \cdot 0$ & 14.5 \\
\hline \multicolumn{12}{|l|}{ S. lactis } \\
\hline NCDO 505 & - & $7 \cdot 0$ & - & 35 & 2 & - & - & $6 \cdot 5$ & 23.5 & $2 \cdot 0$ & 23.0 \\
\hline NCDO 604 & - & $3 \cdot 5$ & - & 28.5 & $3 \cdot 5$ & - & - & $3 \cdot 5$ & $\mathbf{3 1 . 0}$ & $2 \cdot 0$ & 28.0 \\
\hline \multicolumn{12}{|l|}{ S. plantarum } \\
\hline NCDO 1869 & - & $8 \cdot 0$ & 0.5 & $45 \cdot 0$ & $2 \cdot 5$ & - & - & $5 \cdot 0$ & 21.0 & $3 \cdot 5$ & 14.5 \\
\hline NCDO 1870 & 0.5 & 8.0 & - & 46.5 & $3 \cdot 0$ & - & - & $5 \cdot 0$ & 17.0 & 4.5 & 15.5 \\
\hline NCDO 1871 & 0.5 & 6.5 & 0.5 & 46.0 & $3 \cdot 0$ & - & - & 6.0 & 18.0 & $5 \cdot 5$ & 14.0 \\
\hline \multicolumn{12}{|l|}{ S. raffinolactis } \\
\hline NCDO 617 & - & $7 \cdot 5$ & 1.0 & 30.5 & $2 \cdot 5$ & - & - & 5.0 & 50.0 & 3.5 & - \\
\hline NCDO 619 & - & 8.0 & 0.5 & 33.5 & $2 \cdot 0$ & - & 1.0 & 4.5 & 48.0 & $2 \cdot 5$ & - \\
\hline NCDO 2126 & 1.0 & 14.5 & 1.0 & 39.0 & $2 \cdot 0$ & $3 \cdot 0$ & - & $4 \cdot 0$ & 32.5 & $3 \cdot 0$ & - \\
\hline
\end{tabular}

Biochemical tests. The tests were performed using the API 20STREP and API 50CH systems (API Products, Basingstoke, U.K.), according to the manufacturer's instructions. Tests were incubated at $37^{\circ} \mathrm{C}$ and readings were made at 4,24 and $48 \mathrm{~h}$.

\section{RESULTS AND DISCUSSION}

The purified peptidoglycans of NCDO 1869 and NCDO 2155 contained lysine as the dibasic amino acid. Quantitative determinations revealed the presence of group A peptidoglycan types: Lys-serine $_{1}$-alanine ${ }_{1}$ in NCDO 1869, and Lys-alanine - $_{1}$-glycine - $_{1}$-alanine ${ }_{1}$ in NCDO 2155 . The presence of two different cell wall peptidoglycan types in the pea and mastitis strains reinforces the distinctiveness of these taxa. Further, the peptidoglycan types of these taxa are quite different from those of other group N streptococci. The peptidoglycan type of $S$. lactis and $S$. cremoris is Lys-D-aspartic acid (Schleifer \& Kandler, 1972), whereas that of S. raffinolactis is Lysthreonine-alanine (O. Kandler, unpublished).

The long-chain fatty acid composition of the test strains is shown in Table 1. Streptococcus cremoris, $S$. lactis, the pea and mastitis strains possessed closely related fatty acid profiles consisting of predominantly straight-chain saturated, monounsaturated and cyclopropane-ring acids. The major fatty acids in all four taxa consisted of hexadecanoic $\left(\mathrm{C}_{16: 0}\right)$, octadecenoic $\left(\mathrm{C}_{18: 1}\right)$ and cis-11, 12-methylenoctadecanoic $\left(\Delta \mathrm{C}_{19: 0}\right)$ acids (Table 1). Streptococcus raffinolactis also possessed major amounts of $\mathrm{C}_{16: 0}$ and $\mathrm{C}_{18: 1}$. However, $S$. raffinolactis differed from the other taxa examined in lacking cyclopropane-ring acids (cis-11,12-methylenoctadecanoic acid).

Neither menaquinones (vitamin $\mathrm{K}_{2}$ ) nor ubiquinones (coenzyme Q) were detected in the neutral lipid fractions of the three pea isolates (NCDO 1869 to 1871). In contrast, the mastitis streptococci (NCDO 2155, 2156, 2157, 2159) possessed low levels of a quinone which cochromatographed with vitamin $\mathrm{K}_{1}$. On mass spectral analysis the quinones produced a base peak at $m / e 225$, and a second intense peak at $m / e 187$, in accordance with published data for menaquinones (Collins \& Jones, 1981). Peaks corresponding to molecular ions $\left(\mathrm{M}^{+}\right)$were also observed at $m / e 648,716,784$ and 852 (major component in bold) attributable to unsaturated menaquinones with 7,8,9 and 10 isoprene units, respectively. Quantification by HPLC indicated MK-9 constituted the major component (about 56 to $62 \%$ ) together with substantial 
Table 2. Differential biochemical properties of S. garvieae, S. plantarum, S. cremoris, S. lactis and $S$. raffinolactis

$\begin{array}{ccccc}\begin{array}{c}S . \text { garvieae } \\ \text { (NCDO 2155, }\end{array} & \begin{array}{c}S . \text { plantarum } \\ \text { (NCDO 1869, }\end{array} & \text { S. cremoris } & \text { S. lactis } & \text { S. raffinolactis } \\ 2156,2157, & 1870,1871 ; & \text { (NCDO 607, } & \text { (NCDO 712, } & \text { (NCDO 617, } \\ 2159 ; \text { from } & \text { from frozen } & 508,764,924, & 604,505, & 618,619,2112, \\ \text { bovine mastitis) } & \text { peas) } & 1217,1986) & 507,509) & 2114,2136)\end{array}$

\begin{tabular}{|c|c|}
\hline Acid from: ${ }^{*}$ & \\
\hline L-Arabinose & 0 \\
\hline Amygdalin & 100 \\
\hline Arbutin & 100 \\
\hline Cellobiose & 100 \\
\hline Galactose & 100 \\
\hline$\beta$-Gentiobiose & 100 \\
\hline Gluconate & 50 (weak) \\
\hline Inulin & 0 \\
\hline Lactose & 100 \\
\hline Maltose & 75 \\
\hline D-Mannitol & 75 \\
\hline Melibiose & 0 \\
\hline Melizitose & 0 \\
\hline$\alpha$-Methyl-D-glucoside & 0 \\
\hline Raffinose & 0 \\
\hline Ribose & 100 \\
\hline Salicin & 100 \\
\hline L-Sorbose & 0 \\
\hline Sorbitol & 0 \\
\hline Sucrose & 50 \\
\hline D-Tagatose & 50 \\
\hline Trehalose & 100 \\
\hline D-Turanose & 0 \\
\hline D-Xylose & 0 \\
\hline Starch & 0 \\
\hline Hydrolysis of $: \dagger$ & \\
\hline Aesculin & 100 \\
\hline Hippurate & 0 \\
\hline Production of $: \ddagger$ & \\
\hline Arginine dehydrolase & 100 \\
\hline$\alpha$-Galactosidase & 0 \\
\hline$\beta$-Glucuronidase & 100 \\
\hline Pyrrolidonylarylamidase & 100 \\
\hline
\end{tabular}

0
100 (weak)
100
100
0
67
0
0
0
100
100
0
100
0
0
0
100
0
100
100
0
100
67
0
0

100
0

$\begin{array}{rrr}0 & 0 & 33 \\ 0 & 20 & 33 \\ 0 & 80 & 83 \\ 67 & 80 & 100 \\ 100 & 100 & 100 \\ 17 & 80 & 67 \\ 0 & 0 & 0 \\ 0 & 20 & 50 \\ 100 & 100 & 100 \\ 0 & 100 & 100 \\ 0 & 20 & 67 \\ 0 & 0 & 100 \\ 0 & 0 & 50 \\ 0 & 0 & 17 \\ 0 & 0 & 100 \\ 0 & 100 & 17 \\ 17 & 80 & 100 \\ 0 & 0 & 17 \\ 0 & 0 & 0 \\ 0 & 20 & 100 \\ 0 & 0 & 0 \\ 17 & 100 & 100 \\ 0 & 0 & 50 \\ 0 & 0 & 83 \\ 0 & 40 & 100 \\ & & \\ 50 & 100 & 00 \\ 100 & 100 & \end{array}$

* Acid from carbohydrates was determined using the API 50CH system; readings were made at $24 \mathrm{~h}$. All strains produced acid from glucose, fructose, mannose and $\mathrm{N}$-acetylglucosamine; acid was not produced from $\mathrm{D}-$ arabinose, arabitol, adonitol, 2-keto-gluconate, 5-keto-gluconate, dulcitol, erythritol, D-fucose, L-fucose, glycerol, glycogen, inositol, D-lyxose, $\alpha$-methyl-D-mannoside, $\beta$-methylxyloside, rhamnose, $L$-xylose and xylitol.

$\dagger$ Hydrolysis of aesculin and hippurate was determined using the API 20STREP system; readings for hippurate and aesculin hydrolysis were made at $4 \mathrm{~h}$ and $24 \mathrm{~h}$, respectively.

$\ddagger$ Enzyme activity was determined using the API 20 STREP system; readings were made at $4 \mathrm{~h}$. All strains were leucine arylamidase-positive and $\beta$-galactosidase-negative.

amounts of MK-8 (about 25 to $32 \%$ ). Minor amounts of MK-7 (11 to $12 \%$ ) and MK-10 (2 to 3\%) were also detected. The detection of MK-9 in the mastitis isolates serves to distinguish these from the pea strains and $S$. raffinolactis which lack respiratory menaquinones. Major amounts of MK-9 have, however, been previously reported in $S$. cremoris and $S$. lactis (Collins \& Jones, 1979).

The results of the biochemical tests are presented in Table 2. The pea and mastitis strains were readily distinguished from each other, and from $S$. cremoris, $S$. lactis and $S$. raffinolactis. In the study of Garvie et al. (1981), S. lactis and the mastitis isolates were found to be phenotypically indistinguishable. These taxa however can be readily distinguished using the API 50CH and 20STREP systems (Table 2). 
Table 3. Differential characteristics of $S$. garvieae, $S$. plantarum, S. cremoris, $S$. lactis and $S$. raffinolactis

Cell wall peptidoglycan type Major menaquinone Major fatty acids

$\mathrm{G}+\mathrm{C}(\mathrm{mol} \%)$
S. garvieae Lys-Ala 1 -Gly - Ala $_{1}$

$$
\text { MK-9 }
$$

$\mathrm{C}_{16: 0}, \mathrm{C}_{18: 1}$, $\Delta \mathrm{C}_{19: 0}$ $38 \cdot 3-38 \cdot 7$
S. plantarum

Lys-Ser $_{1}-\mathrm{Ala}_{1}$

S. cremoris

Lys-D-Asp 1

$\mathrm{C}_{16: 0}, \mathrm{C}_{18: 1}$, $\Delta \mathrm{C}_{19: 0}$ $36 \cdot 9-38 \cdot 1$
MK-9

$\mathrm{C}_{16: 0}, \mathrm{C}_{18: 1}$,

$\triangle \mathrm{C}_{19: 0}$

$34 \cdot 8-35 \cdot 6$
S. lactis

Lys-D-Asp

MK-9
$\mathrm{C}_{16: 0}, \mathrm{C}_{18: 1}$,

$\Delta \mathrm{C}_{19: 0}$

$34 \cdot 4-36 \cdot 3$
S. raffinolactis

Lys-Thr ${ }_{1}-\mathrm{Ala}_{1}$<smiles>[131I-][131I-]</smiles>

$40 \cdot 0-42 \cdot 6$

In the earlier study of Garvie et al. (1981) the mastitis and pea isolates were shown to be genetically quite distinct from each other, and from other group $\mathrm{N}$ streptococci. The results of the present study confirm this distinctiveness. The mastitis and pea strains can be distinguished from $S$. raffinolactis in possessing high levels of $c i s-11,12$-methylenoctadecanoic acid, whilst they differ from $S$. cremoris, $S$. lactis and each other in peptidoglycan composition (see Table 3 ). The mastitis and pea isolates are also biochemically quite distinct (Table 2). Thus on the basis of the present and earlier studies (Cavett \& Garvie, 1967; Garvie et al., 1981) we consider the pea and mastitis strains constitute two new species. The isolates from frozen peas are named Streptococcus plantarum sp. nov. and those from mastitis, Streptococcus garvieae sp. nov.

\section{Description of Streptococcus plantarum sp. nov. (L. gen. pl. noun plantarum of plants)}

Colonies on blood agar or nutrient agar are circular, smooth and entire. Non-pigmented. Nonhaemolytic. Spheres or ovoid cells elongated in the direction of the chain; mostly in pairs or short chains. Gram-positive, non-motile. Facultatively anaerobic. Catalase negative. Growth at $10^{\circ} \mathrm{C}$ but not at $40^{\circ} \mathrm{C}$. Grows in $4 \%(\mathrm{w} / \mathrm{v}) \mathrm{NaCl}$. Chemo-organotroph: metabolism fermentative. Acid produced from amygdalin, arbutin, cellobiose, dextrin, fructose, glucose, maltose, mannose, D-mannitol, melizitose, $N$-acetylglucosamine, salicin, sucrose and trehalose. Acid not produced from adonitol, D-arabinose, L-arabinose, D-arabitol, L-arabitol, 2ketogluconate, 5-ketogluconate, dulcitol, erythritol, D-fucose, L-fucose, galactose, gluconate, glycogen, glycerol, inositol, inulin, lactose, D-lyxose, melibiose, $\alpha$-methyl-D-glucoside, $\alpha$-methyl$\mathrm{D}$-mannoside, $\beta$-methylxyloside, raffinose, ribose, rhamnose, L-sorbose, D-tagatose, D-xylose, Lxylose and xylitol. Variable results may be obtained for $\beta$-gentiobiose and D-turanose. Aesculin hydrolysed. Starch, hippurate and gelatin not hydrolysed. Leucine arylamidase positive. $\beta$ Galactosidase, $\beta$-glucuronidase, arginine dehydrolase and pyrrolidonylaryl-amidase negative. Some strains $\alpha$-galactosidase positive. Contains Lancefield group $\mathbf{N}$ antigen.

The peptidoglycan type of NCDO 1869 is Lys-serine $_{1}$-alanine ${ }_{1}$. Menaquinones are absent. Major non-hydroxylated long-chain fatty acids are hexadecanoic, octadecenoic $(\omega 7)$ and cis11,12-methylenoctadecanoic acid $\left(\Delta \mathrm{C}_{19: 0}\right)$. The guanine plus cytosine content of DNA ranges from 36.9 to $38.1 \mathrm{~mol} \%$ as determined by melting temperature $\left(T_{m}\right)$. The type strain is NCDO 1869. Source: frozen peas.

\section{Description of Streptococcus garvieae sp. nov. (garvieae of Garvie; named for E. I. Garvie, a British microbiologist)}

Colonies on blood agar or nutrient agar are circular, smooth and entire. Non-pigmented. Nonhaemolytic. Ovoid cells elongated in the direction of the chain; mostly in pairs or short chains. Gram-positive, non-motile. Facultatively anaerobic. Catalase negative. Growth at $10{ }^{\circ} \mathrm{C}$ and $40^{\circ} \mathrm{C}$; no growth at $45^{\circ} \mathrm{C}$. Grows in $4 \%(\mathrm{w} / \mathrm{v}) \mathrm{NaCl}$. Chemoorganotroph: metabolism fermentative. Acid produced from galactose, glucose, fructose, cellobiose, amygdalin, arbutin, mannose, ribose, trehalose, salicin, $\beta$-gentiobiose and $N$-acetylglucosamine. Acid not produced from D-arabinose, L-arabinose, D-arabitol, L-arabitol, adonitol, 2-ketogluconate, 5-ketogluconate, dulcitol, erythritol, D-fucose, L-fucose, glycogen, inulin, inositol, melibiose, melezitose, $\beta$ methylxyloside, $\alpha$-methyl-D-glucoside, $\alpha$-methyl-D-mannoside, D-lyxose, raffinose, rhamnose, Lsorbose, sorbitol, D-turanose, xylitol, D-xylose and L-xylose. Variable results may be obtained for 
maltose, D-mannitol, sucrose and D-tagatose. Aesculin hydrolysed. Starch and hippurate hydrolysis negative. $\beta$-Glucuronidase, arginine dehydrolase, leucine arylamidase and pyrrolidonylarylamidase positive. $\alpha$-Galactosidase and $\beta$-galactosidase negative.

The peptidoglycan type of NCDO 2155 is Lys-ala ${ }_{1}-$ gly $_{1}-$ ala $_{1}$. Low levels of menaquinones produced with MK-9 predominating. Major non-hydroxylated long-chain fatty acids are hexadecanoic, octadecenoic $(\omega 7)$ and cis-11,12-methylenoctadecanoic acid $\left(\Delta \mathrm{C}_{19: 0}\right)$. The guanine plus cytosine content of DNA ranges from 38.3 to $38.7 \mathrm{~mol} \%$ as determined by melting temperature $\left(T_{m}\right)$. The type strain is NCDO 2155 . Source: bovine mastitis.

We are grateful to API (Basingstoke, U.K.) for the gift of 50CH and 20STREP systems.

\section{REFERENCES}

CAvett, J. J. \& GARvie, E. I. (1967). Biochemical and serological characters of three strains of streptococci previously reported as Streptococcus cremoris isolated from deep-frozen peas after thawing. Journal of Applied Bacteriology 30, 377-381.

Cavett, J. J., Dring, G. J. \& KNIGHT, A. W. (1965). Bacterial spoilage of thawed frozen peas. Journal of Applied Bacteriology 28, 241-251.

Collins, M. D. \& JoNES, D. (1979). The distribution of isoprenoid quinones in streptococci of serological groups D and N. Journal of General Microbiology 114, 27-33.

Collins, M. D. \& JoNEs, D. (1981). Distribution of isoprenoid quinone structural types in bacteria and their taxonomic implications. Microbiological Reviews 45, 316-354.

Collins, M. D., Pirouz, T., Goodfellow, M. \& MINNIKIN, D. E. (1977). Distribution of menaquinones in actinomycetes and corynebacteria. Journal of General Microbiology 100, 221-230.

Collins, M. D., McCarthy, A. J. \& Cross, T. (1982). New highly saturated members of the vitamin $\mathbf{K}_{2}$ series from Thermomonospora. Zentralblatt für Bakteriologie, Parasitenkunde, Infektionskrankheiten und Hygiene (I. Abteilung, Originale C) 3, 358-363.
Deibel, R. H. \& Seeley, H. W., JR (1974). Streptococcaceae. In Bergey's Manual of Determinative Bacteriology, 8th edn. Edited by R. E. Buchanan \& N. E. Gibbons. Baltimore: Williams \& Wilkins.

Farrow, J. A. E., Jones, D., Phillips, B. A. \& Collins, M. D. (1983). Taxonomic studies on some group D streptococci. Journal of General Microbiology 129, 1423-1432.

GARVIE, E. I. (1978). Streptococcus raffinolactis (OrlaJensen and Hansen); a group $N$ streptococcus found in raw milk. International Journal of Systematic Bacteriology 28, 190-193.

Garvie, E. I., Farrow, J. A. E. \& Phillips, B. A. (1981). A taxonomic study of some strains of streptococci which grow at $10^{\circ} \mathrm{C}$ but not at $45^{\circ} \mathrm{C}$ including Streptococcus lactis and Streptococcus cremoris. Zentralblatt für Bakteriologie, Parasitenkunde, Infektionskrankheiten und Hygiene (I. Abteilung, Originale C) 2, 151-165.

SCHLEIFER, K. H. \& KANDler, O. (1972). Peptidoglycan types of bacterial cell walls and their taxonomic implications. Bacteriological Reviews 36, 407-477.

Skerman, V. B. D., McGowan, V. \& SNeath, P. H. A. (editors) (1980). Approved Lists of Bacterial Names. International Journal of Systematic Bacteriology 30, $225-420$. 